\title{
Rust resistance and mating system in Eucalyptus grandis Hill ex Maiden progenies
}

\author{
Resistência à ferrugem e sistema de reprodução \\ em progênies de Eucalyptus grandis Hill ex Maiden
}

\author{
Gustavo Henrique Bertoncini ${ }^{1}$, Evandro Vagner Tambarussi ${ }^{2}$, Alexandre Magno Sebbenn ${ }^{3}$, \\ Cristiano Bueno de Moraes ${ }^{4}$, Lorena Gama Teixeira ${ }^{5}$, Edson Luiz Furtado ${ }^{6}$, \\ Léo Zimback ${ }^{7}$ e Edson Seizo Mori ${ }^{6}$
}

\begin{abstract}
Resumo
Populações de Eucalyptus grandis foram introduzidas no Brasil a partir de Queensland e New South Wales, Austrália. No entanto, no Brasil, estas plantas têm sido severamente prejudicadas pela ferrugem (Puccinia psidii Winter). Portanto, objetivamos estimar os parâmetros do sistema de reprodução e a herdabilidade para resistência a ferrugem em $E$. grandis por meio de um teste de progênies. Nós avaliamos a resistência a ferrugem em vinte e cinco progênies de polinização aberta, que foram severamente afetadas por $P$. psidii, utilizando quatro marcadores de microssatélites. A taxa de cruzamento foi significativamente menor do que a unidade $\left(t_{m}=0.782\right)$ e a diferença entre as taxas multilocus e unilocus foi significativamente maior do que zero $\left(t_{m}-t_{s}=0.077\right)$. Esses resultados mostram que algumas sementes eram endogâmicas como confirmado pelo índice de fixação $\left(F_{o}=0,144, \mathrm{P}<0,05\right)$. Além disso, a correlação de paternidade $\left(r_{p}=\right.$ $0,102)$ indicou um pequeno número de irmãos-completos dentro de progênies. O coeficiente de parentesco estimado dentro de progênies $(\rho)$ foi significativamente maior $(0,421)$ do que o esperado para meios-irmãos $(0,25)$. O coeficiente de herdabilidade entre progênies $\left(h_{f}^{2}=0,956\right)$, bem como em nível individual $\left(h_{i}^{2}=0,634\right)$ e dentro de progênies $\left(h_{w}^{2}=0,515\right)$ foram elevados. Nossos resultados evidenciaram forte controle genético para o caráter resistência à ferrugem, indicando que o melhoramento dessas populações pode ser feito pela seleção massal ou pela seleção simultânea entre e dentro de progênies.
\end{abstract}

Palavras-chave: Parâmetros genéticos; teste de progênie; Puccinia psidii; sistema de reprodução.

\begin{abstract}
Populations of Eucalyptus grandis were introduced into Brazil from Queensland and New South Wales, Australia. However, in Brazil, these plants have been severely injured by rust (Puccinia psidii Winter). Therefore, we aimed at estimating mating system parameters and heritability of rust resistance in $E$. grandis through progeny testing. We evaluated rust resistance in twenty-five open-pollinated progenies severely affected by $P$. psidii using four microsatellite markers. Outcrossing rate was significantly lower than unity $\left(t_{m}=0.782\right)$, and the difference between multilocus and single-locus was significantly higher than zero ( $\left.t_{m}-t_{s}=0.077\right)$. These findings highlight that a few seeds are inbred lines as confirmed by the fixation index $\left(F_{0}=0.144, \mathrm{P}<0.05\right)$. Furthermore, the paternity correlation $\left(r_{p}=0.102\right)$ indicated a small number of full-sibs within progenies. The estimated relatedness coefficient within progenies $(\rho)$ was significantly higher $(0.421)$ than that expected for half-sibs $(0.25)$. The mean heritability coefficient among progenies $\left(h_{f}^{2}=0.956\right)$, as well as at the individual level $\left(h_{i}^{2}=0.634\right)$ and within a progeny $\left(h_{w}^{2}=0.515\right)$ were high.
\end{abstract}

\footnotetext{
${ }^{1}$ Engenheiro Florestal no Departamento de Proteção Vegetal. UNESP - Universidade Estadual Paulista Júlio de Mesquita Filho / Faculdade de Ciências Agronômicas de Botucatu. Rua Doutor José Barbosa de Barros, 1780 - Caixa Postal: 237 Botucatu, SP, Brasil. E-mail: ghbertoncini@fca.unesp.br

${ }^{2}$ Professor Adjunto no Departamento de Engenharia Florestal. UNICENTRO - Universidade Estadual do Centro Oeste. Campus Irati. PR 153, Km 7- 84500-000 - Riozinho, Irati, PR. E-mail: evandro.tambarussi@pq.cnpq.br

3Pesquisador Doutor. IF - Instituto Florestal de São Paulo. Estação Experimental de Tupi. Rodovia Luiz de Queiroz, Km 149,5 - Tupi - 13400-970 - Piracicaba, SP, Brasil.

${ }^{4}$ Professor Adjunto no Departamento de Ciências Florestais. UFT - Universidade Federal de Tocantins. Campus de Gurupi. Setor Central - 77402970 - Gurupi, TO, Brasil. E-mail: cb moraes2004@yahoo.com.br

${ }^{5}$ Graduanda em Engenharia Florestal. UFT - Universidade Federal de Tocantins. Campus de Gurupi. Setor Central 77402970 - Gurupi, TO, Brasil. E-mail: lorenagamaeng@gmail.com

${ }^{6}$ Professor Titular do Departamento de Proteção Vegetal. UNESP - Universidade Estadual Paulista Júlio de Mesquita Filho / Faculdade de Ciências Agronômicas de Botucatu. Rua Doutor José Barbosa de Barros, 1780 - Caixa Postal: 237 - Botucatu, SP, Brasil. E-mail: elfurtado@fca.unesp.br; esmori@fca.unesp.br

${ }^{7}$ Pesquisador Aposentado. IF - Instituto Florestal do Estado de São Paulo. Floresta Estadual de Botucatu. Avenida José Ítalo Bacchi s/n - Caixa-postal: 153 - 18603-970 - Botucatu, SP, Brasil.
}

Sci. For., Piracicaba, v. 45, n. 114, p. 405-413, jun. 2017 DOI: dx.doi.org/10.18671/scifor.v45n114.16 
Bertoncini et al. - Rust resistance and mating system in Eucalyptus grandis Hill ex Maiden progenies

Given that, our results indicated a strong genetic control on rust resistance and the feasibility in improving the populations by mass selection for both among and within progenies.

Keywords: Genetic parameters, progeny test; Puccinia psidii, tree breeding.

\section{INTRODUCTION}

Eucalyptus grandis Hill. ex Maiden is a timber species occurring naturally in Australia and has a rapid growth under tropical and subtropical conditions. Its wood has good quality for pulp and paper, sawmill, and hardboard industries (MIRANDA et al., 2013). In Brazil, however, a lot of species of the genus Eucalyptus have been damaged by diseases such as rust (Puccinia psidii Winter), which represents today one of the most harmful diseases affecting them (PINTO et al., 2014).

This fungal disease is able to overcome adverse environmental conditions causing, as a result, expressive losses to commercial plantations. In Brazil, it was first described in 1944, in seedlings of E. citriodora (currently named Corymbia citriodora) in the state of Rio de Janeiro (JOFFILY, 1944). Nevertheless, the first alarming report came in 1973, when 400,000 seedlings of $E$. grandis were affected in the state of Espírito Santo (FERREIRA, 1989). Despite the damages caused by rust, outbreaks occur sporadically (FERREIRA, 1989). In 1980, a severe outbreak jeopardized around 300 ha of six-month-old E. grandis plantation established by Vale do Rio Doce, in the state of Minas Gerais (FERREIRA, 1989). Later, in 1991, rust outbreaks were then recorded in forested areas under reform in Paraíba Valley, in São Paulo state; from 1996 and beyond, the disease spread over the entire state (TAKAHASHI et al., 1997). Currently, the disease still affects vulnerable provenances of eucalyptus with less than 2 years, in the states of São Paulo, Minas Gerais, Bahia, and Espírito Santo which are the main producers of wood from these species.

The unfeasibility of chemical control and the lack of registered products have called the attention of the forest companies towards the use of resistant plants to overcome the disease (RUIZ; ALFENAS, 1989; TAKAHASHI et al., 1997) as it may be an effective method of control. Eucalyptus breeding programs have reached significant gains in Brazil. This success is due to the application of quantitative genetics and molecular techniques such as DNA markers, which have contributed to the development of resistant materials. Hence, genetic parameters are crucial to defining the breeding strategies since heritability is one of the most important factors influencing the effectiveness of selection. Therefore, it is of utmost relevance to find methods that reduce the high time-consuming normally spent in progeny tests (VASCONCELLOS; VALOIS, 1986).

Plant breeding programs have used molecular markers, directly and indirectly, to assist breeders in selecting genes of agricultural or forestry interest, by characterizing and identifying clones (parental and phylogeny tests), as well as planning crosses (FUCHS et al., 2015; VAILLANCOURT et al., 1998). BRONDANI et al. (1998) listed a few comparative advantages of these genetic markers regarding co-dominance inheritance, such as multiallelism. Multiallelic microsatellites increase the chances of genotype uniqueness within a population, enabling individual identification and monitoring of gene flow mediated by pollen and seed dispersal (BUTCHER et al., 2000).

This study aimed at estimating the heritability coefficients for rust resistance in seedlings of $E$. grandis affected by $P$. psidii through progeny testing and to identify resistant progenies for further cloning. Moreover, since heritability is affected by the degree of relatedness within a progeny, as well as the composition of open-pollinated progenies such as self-sibs, half-sibs, full-sibs, and selfhalf-sibs (NAMKOONG, 1966; SEBBENN, 2006; SQUILLACE, 1974), we analyzed mating system parameters to estimate relatedness coefficients using four microsatellite loci. Accordingly, these coefficients were used to correct any additive effect of genes, obtaining more accurate estimates of the coefficient of heritability.

\section{MATERIAL AND METHODS}

\section{Field methodology and disease evaluation}

Eucalyptus grandis progeny seedlings were planted in July of 2001, in São Miguel Arcanjo - SP, Brazil (latitude $23^{\circ} 52^{\prime} 42^{\prime \prime} \mathrm{S}$ and longitude $47^{\circ} 59^{\prime} 50^{\prime \prime} \mathrm{W}$ ). For the progeny test, we used open- 
pollinated seeds from two landraces developed by Cia Suzano de Papel e Celulose from two Australian origins: Coffs Harbour (Northern New South Wales) and Atherton (Northern Queensland). This way, we used material from the first generation of the Australian plants, which was considered as a single population.

The statistical design was a randomized complete block with 25 progenies, 24 plants per plot and four replications (blocks), whose plants were arranged in a $3 \mathrm{~m}$ x $2 \mathrm{~m}$ spacing. A scoring scale representing the percentage of injured plants was used, as proposed by Zamprogno et al. (2008). In such proposal, " 0 " stands for a plant free from symptoms (healthy plant); " 1 " is for few rust pustules on the leaves; " 2 " is for typical rust pustules, usually sparse and only occasionally abundant on a limb and young leaves; and " 3 " is for a plant with typical pustules being abundant on stem, petioles of younger leaves and on the ends of branches and main stem, compromising apical dominance (apical necrosis). The assessments were performed by observing pustule shape, distribution, and frequency of affected plants, in addition to assessing plant field performance. The field data were collected in September of 2003 when plants were two years old. A variance analysis was performed by converting data into $\sqrt{x+0.5}$ (MIRANDA et al., 2013), in which $x$ is the score of a plant. The data normality was tested by the Shapiro-Wilk's W test (SAS, 1999), which showed a normal distribution $(\mathrm{W}=0.9479, \mathrm{P}=0.0016)$.

\section{Microsatellite analysis}

Leaves were randomly collected from eight individuals of each progeny; thus, genetic analysis was based on a set of 200 samples. DNA was extracted according to Doyle and Doyle (1990). We have tested ten loci among those proposed by BRONDANI et al. (1998), which were obtained from the four most polymorphic ones, being enough for a mating system analysis (RITLAND; JAIN, 1981). Amplifications were carried out using an MJ Research, Inc. PTC-100 Programmable Thermal Controller thermocycler. The thermocycler profile was as follows: $2 \mathrm{~min}$ at $96^{\circ} \mathrm{C}, 33$ cycles of $1 \mathrm{~min}$ at $94{ }^{\circ} \mathrm{C}$, annealing at $56{ }^{\circ} \mathrm{C} 1 \mathrm{~min}$ and extension at $72{ }^{\circ} \mathrm{C}$ for $2 \mathrm{~min}$ and a final extension step of $72{ }^{\circ} \mathrm{C}$ for $5 \mathrm{~min}$. The total volume of the mixture was $12.7 \mu \mathrm{L}$. The reagents included $1 \mu \mathrm{L}$ PCR buffer $10 \mathrm{x}, 3 \mu \mathrm{l}$ DNA $(4 \mathrm{ng} / \mu \mathrm{L}), 0.6 \mu \mathrm{L}$ of each primer $(10 \mu \mathrm{M}), 1 \mu \mathrm{L}$ dNTP solution $(0.5 \mathrm{mM})$, $0.125 \mu \mathrm{L}(1 \mathrm{U})$ of Taq DNA polymerase (Invitrogen Life Technologies) and $0.39 \mu \mathrm{L}$ of $\mathrm{MgCl}_{2}(50$ $\mathrm{mM}$ ) supplemented with $6 \mu \mathrm{L}$ MilliQ water. The amplification products were electrophoresed on $3 \%$ agarose gel, stained in an ethidium bromide bath at $2 \%$ ( $2 \mathrm{ml}$ in $1.5 \mathrm{~L}$ of water for 1 hour), and observed under ultraviolet light.

\section{Mating system analysis}

The mating system of the progenies was analyzed under mixed-mating and selfing models (RITLAND; JAIN, 1981; RITLAND, 1989), with the aid of multilocus MLTR software version 3.1 (RITLAND, 2002). The estimated parameters were pollen and ovule allele frequency, fixation index of mother trees $\left(F_{m}\right)$, multilocus $\left(t_{m}\right)$ and single-locus $\left(t_{s}\right)$ outcrossing rates, as well as the rate of mating among relatives $\left(t_{m}-t_{s}\right)$, selfing $\left(r_{s}\right)$ and paternity correlation $\left(r_{p}\right)$. The $95 \%$ confidence interval $(95 \% \mathrm{CI})$ of the estimated parameters was calculated based on 1,000 bootstraps among individuals within a progeny array. The mating system parameters were used to estimate effective number of pollen donors $\left(N_{s p}=1 / r_{p}\right)$, as proposed by Ritland (1989). Moreover, we estimated pairwise relatedness for self-sibs $\left(P_{s s}=\left(1-t_{m}\right)^{2}\right)$, half-sibs $\left(P_{h s}=t_{m}^{2}\left(1-r_{p}\right)\right)$, full-sibs $\left(P_{f s}=t_{m}^{2} r_{p}\right)$, and self-half-sibs $\left[P_{s h s}=2 t_{m}\left(1-t_{m}\right)\right]$, and mean relatedness coefficient within progeny array (SEBBENN, 2006). In order to estimate $\rho$, the negative $F_{m}$ values were assumed as zero, since $\rho$ was derived from inbreeding coefficient (range from zero to 1 ) and not from fixation index (range from -1 to 1 ).

$\rho=0.25\left(1+F_{m}\right)\left[4 s+\left(t_{m}^{2}+t_{m} s r_{s}\right)\left(1+r_{p}\right)\right]$, where ${ }^{s}$ is theselfingcorrelation, $s=1-t_{m}$ (RITLAND, 1989 , used $\rho$ in place of $\mathrm{C}_{1}$ ).

Progeny inbreeding was quantified using the fixation index, $F_{0}=1-\left(H_{0} / H_{\varepsilon}\right)$, wherein $H_{0}$ and $H_{\epsilon}$ are observed and expected heterozygosity, respectively (NEI, 1978). Plants from the same progeny display at least one of the maternal alleles, which can overestimate the gene frequencies. Therefore, $F_{0}$ among progenies was estimated using $H_{0}$ of the population, and $H_{\theta}$ for gene frequencies of the pollen pool. $H_{0}$ was estimated using the FSTAT software (GOUDET, 1995), and

Sci. For., Piracicaba, v. 45, n. 114, p. 405-413, jun. 2017 DOI: dx.doi.org/10.18671/scifor.v45n114.16 
$H_{\epsilon}$ by the equation $H_{e}=1-\sum p^{2}$, wherein $p$ is the allele frequency at each locus (NEI, 1978). The statistical significance of $\bar{F}_{o}$ values was tested by permuting alleles across individuals by FSTAT, which was also used to estimate the total $(k)$ and the mean number of alleles per locus $(A)$. The 95\% CI of these measures was estimated by the following equations:

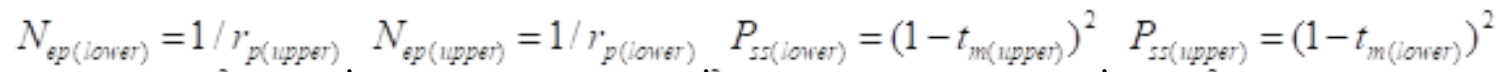

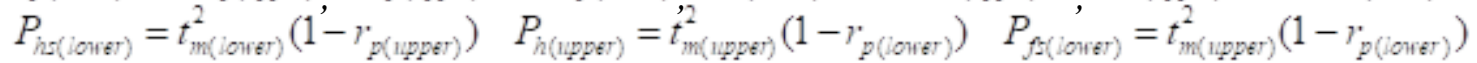

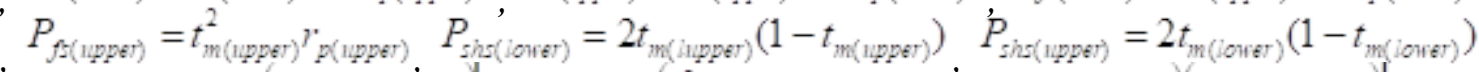

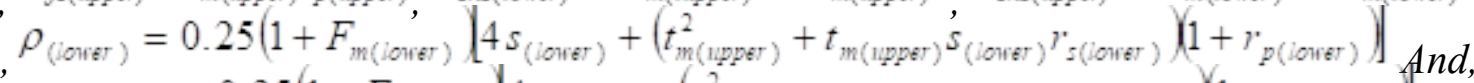

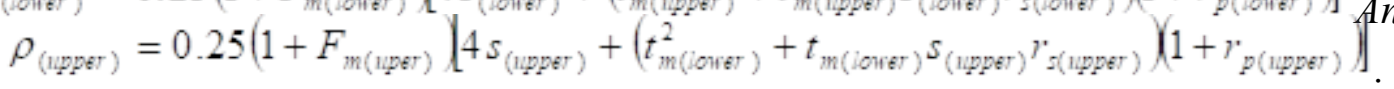

\section{Variance analysis and estimation of genetic parameters}

The variance analysis (ANOVA) in this study was based on polygenic inheritance of rust resistance, even if some studies have found that it is associated to other major genes (KUHLMAN et al., 1997). ANOVA was carried out on individual tree data for each progeny test using the GLM procedure (SAS, 1999). Variance components were estimated by the option restricted maximum likelihood (REML) of the VARCOMP procedure for unbalanced data, following the linear statistical model below:

$$
Y_{i j k}=\mu+b_{i}+p_{j}+e_{i j}+d_{i j k} \text {, }
$$

where: $Y_{i j k}$ is the phenotypic value of the $k^{\text {th }}$ individual of the $j^{\text {th }}$ progeny and the $i^{\text {th }}$ replicate (blo$\mathrm{ck}) ; \mu$ is the mean term; $b_{i}$ is the fixed effect of the $i^{- \text {th }}$ replicate; $p_{j}$ is the random effect of the $j^{\text {th }}$ progeny; $e_{i j}$ is the random effect of the interaction between the $j^{-{ }^{\text {th }}}$ progeny and the $i^{\text {-th }}$ replicate; $d_{i j k}$ is the random effect of the $k^{\text {th }}$ tree within the $j^{- \text {th }}$ progeny of the $i^{\text {th }}$ replicate; $i=1, \ldots, b$ (b is the number of replicates); $j=1, \ldots, p$ ( $p$ is the number of progeny); $k=1, \ldots, n$ ( $n$ is the harmonic mean of trees per plot).

From the ANOVA the following components were estimated: $\sigma_{f_{2}}^{2}$ (variance among progenies); $\sigma_{\varepsilon}^{2}$ (variance of the interaction between progenies and replicates); $\sigma_{w}^{2}$ (phenotypic variance within plots), $\sigma_{P}^{2}$ (total phenotypic variance, $\sigma_{P}^{2}=\sigma_{w}^{2}+\sigma_{\varepsilon}^{2}+\sigma_{f}^{2}$ ); $\sigma_{A}^{3}=\sigma_{f}^{2} / \rho$ (additive genetic variance, where $\rho$ is the average coefficient of relatedness within progenies). The $\sigma_{A}^{2}$ was estimated for two models: i) assuming that the open-pollinated progenies were generated by random-mating system and were half-sibs; and ii) assuming that the open-pollinated progenies were generated by mixed-mating system and were composed of a combination of different relatedness levels such as self-sibs, halfsibs, full-sibs and self-half-sibs (SQUILLACE, 1974). The coefficients of heritability were estimated as described by Namkoong (1979), in which the individual heritability $\left(h_{i}^{2}\right)$ was calculated by:

$$
h_{i}^{2}=\frac{\sigma_{A}^{2}}{\sigma_{f}^{2}+\sigma_{e}^{2}+\sigma_{w}^{2}} \text {, }
$$

The mean heritability among progenies $\left(h_{f}^{2}\right)$ by:

$$
h_{f}^{2}=\frac{\rho \sigma_{A}^{2}}{\sigma_{f}^{2}+\frac{\sigma_{t}^{3}}{b}+\frac{\sigma_{w}^{2}}{n b}} \text { and, finally, }
$$

The mean heritability within progeny $\left(h_{w}^{2}\right)$ by:

$$
h_{w}^{2}=\frac{(1-\rho) \sigma_{A}^{2}}{\sigma_{w}^{2}}
$$

\section{RESULTS AND DISCUSSION}

\section{Mating system}

Because of technical difficulties in microsatellite amplification, mating system and genetic diversity analyses were based on four to eight genotypes of the progenies, totaling 184 samples. The 
fixation index of mother plants $\left(F_{m}\right)$ estimated for progenies was lower than zero, indicating the absence of inbreeding (Table 1 ). The multilocus outcrossing rate was significantly lower than unity $\left(t_{m}=0.782, \mathrm{P}<0.05\right)$, which ranged among seed trees from 0.347 to 1.0 (Figure 1$)$, suggesting in this case self-fertilization $\left(s=1-t_{m}=0.218\right)$.

Table 1. Mating system, genetic diversity, inbreeding indexes, and heritability in open-pollinated progenies of Eucalyptus grandis at $95 \%$ of confidence interval (CI).

Tabela 1. Sistema de reprodução, diversidade genética, índices de endogamia e herdabilidade em progênies de polinização aberta de Eucalyptus grandis com $95 \%$ de intervalo de confiança (IC).

\begin{tabular}{lc}
\hline Parameter & Mean (95\% Cl) \\
\hline Mother trees fixation index: $F_{m}$ & $-0.125(-0.167$ to -0.080$)$ \\
Multilocus outcrossing rate: $t_{m}$ & $0.782(0.700$ to 0.906$)$ \\
Mating among relatives: $t_{m}-t_{s}$ & $0.077(0.076$ to 0.080$)$ \\
Selfing correlation: $r_{s}$ & $0.729(0.499$ to 0.984$)$ \\
Multilocus paternity correlation: $r_{p}$ & $0.102(0.001$ to 0.205$)$ \\
Effective number of pollen donors: $N_{e p}$ & $9.8(4.9$ to 1000.0$)$ \\
Pairwise frequency of self-sibs: $P_{S S}$ & $0.05(0.01$ to 0.09$)$ \\
Pairwise frequency of half-sibs: $P_{H S}$ & $0.55(0.39$ to 0.82$)$ \\
Pairwise frequency of full-sibs: $P_{F S}$ & $0.06(0.00$ to 0.10$)$ \\
Pairwise frequency of self-half-sibs: $P_{S H S}$ & $0.34(0.13$ to 0.54$)$ \\
Coefficient of relatedness within progeny: $\rho=2 \Theta$ & $0.421(0.310$ to 0.510$)$ \\
Mean number of alleles: $A$ & $3.7(3.3$ to 4.2$)$ \\
Observed heterozygosity: $H_{O}$ & $0.527(0.410$ to 0.644$)$ \\
Expected heterozygosity: $H_{e}$ & $0.615(0.520$ to 0.710$)$ \\
Fixation index within progeny: $F_{O}$ & $0.144(0.07$ to 0.218$)$ \\
Heritability among progenies: $h_{f}{ }_{f}$ & 0.956 \\
Heritability at the individual level (half-sibs): $h^{2}{ }_{i}$ & 1.067 \\
Heritability within progeny (half-sibs): $h^{2}{ }_{w}$ & 1.121 \\
Heritability among progeny (open-pollinated): $h_{f}{ }_{f}$ & $0.956(0.956$ to 0.956$)$ \\
Heritability at individual level (open-pollinated): $h^{2}{ }_{i}$ & $0.634(0.523$ to 0.860$)$ \\
Heritability within progeny (open-pollinated): $h^{2}{ }_{W}$ & $0.515(0.359$ to 0.832$)$ \\
\hline
\end{tabular}

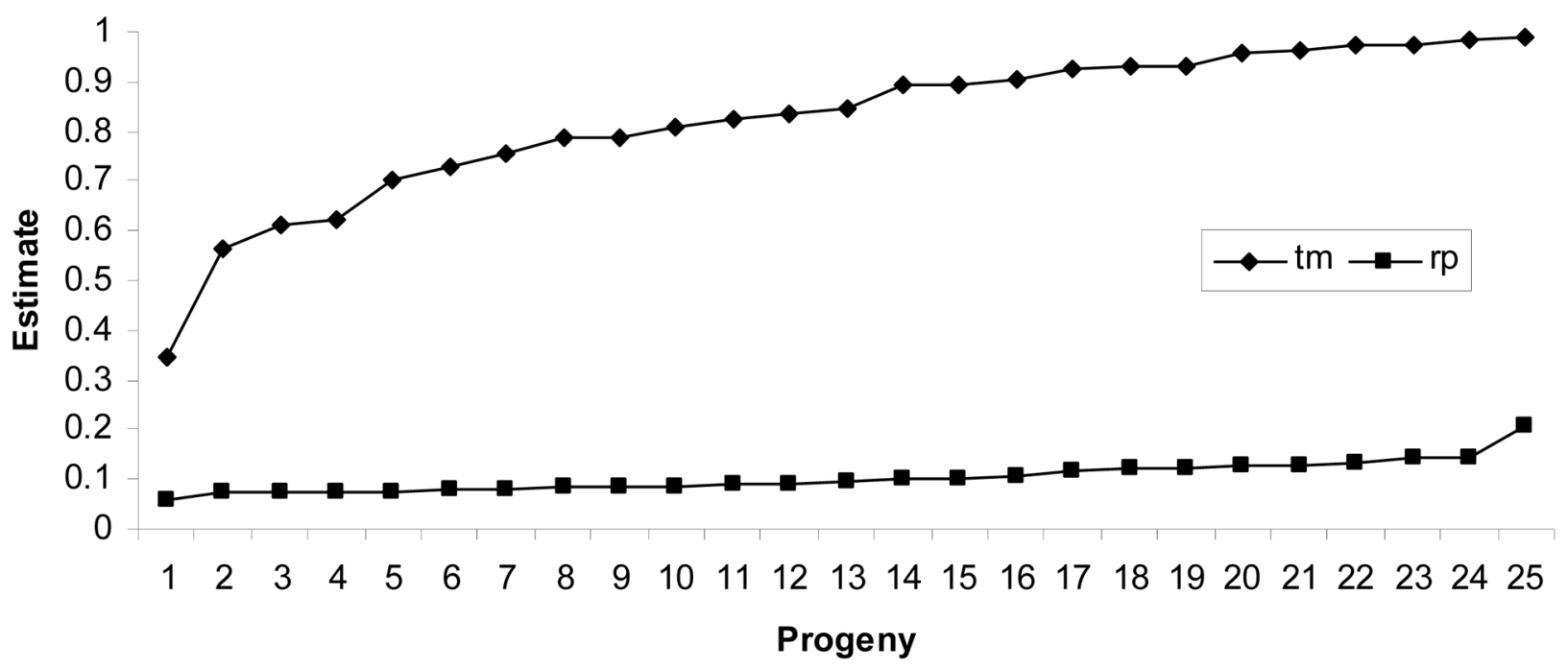

Figure 1. Multilocus outcrossing rate $\left(t_{m}\right)$ and paternity correlation $\left(r_{p}\right)$ estimates for each progeny.

Figura 1. Taxa de cruzamento multilocus $\left(t_{m}\right)$ e correlação de paternidade $\left(r_{p}\right)$ estimada para cada progênie.

Considering the $95 \% \mathrm{CI}$, the difference between multilocus and single-locus outcrossing rates was significantly higher than zero $\left(t_{m}-t_{s}=0.077\right)$, which denotes mating among relatives. The selfing correlation $\left(r_{s}\right)$ was significantly higher than zero $\left(r_{s}=0.729\right)$, showing significant individual variation in outcrossing rate (Figure 1$)$. The paternity correlation $\left(r_{p}=0.102\right)$ was significantly higher than zero $(\mathrm{P}<0.05)$, and within progeny varied from 0.059 to 0.205 (Figure 1 ); therefore, a few individuals are full-sibs within a progeny. The seed trees were effectively fertilized by mean of 9.8 pollen donors $\left(N_{\epsilon p}\right)$, and the progenies were mainly compounded by half-sibs $\left(P_{H S}=0.55\right)$ 
and self-half-sibs $\left(P_{\text {SHS }}=0.34\right)$. Thus, the mean relatedness coefficient within progeny $(\rho=0.421)$ was significantly higher than expected in half-sib progenies $(\rho=0.25)$. The mean number of alleles was 3.7, and observed $\left(H_{0}\right)$ and expected $\left(H_{\theta}\right)$ heterozygosity were 0.527 and 0.615 , respectively. The fixation index for mean progeny was significantly higher than zero $\left(F_{o}=0.144\right)$, which denotes inbreeding occurrence.

There was a significant difference for rust resistance among progenies. The heritability coefficient among progenies $\left(h_{f}^{2}=0.956\right)$ was close to unity, which means this trait is under strong genetic control and the population can be improved by selection. For half-sibs within the same progeny, the heritability coefficient at the individual level $\left(h_{i}^{2}=1.067\right)$ and within the progeny $\left(h_{w}^{2}=1.121\right)$ were higher than unity, showing that the model was inadequate to estimate these parameters. However, these numbers decreased when the additive genetic variance for mating system parameters was adjusted, obtaining reliable values for the estimates $\left(h_{i}^{2}=0.634 ; h_{w}^{2}=0.515\right)$. Therefore, it is important to keep the hypothesis of easy control of rust resistance by means of mass selection between progenies, or even within the same progeny.

Mating system analysis showed different degrees of relatedness among individuals, besides inbreeding from selfing and mating among relatives. Therefore, in this case, heritability estimates for quantitative traits should consider such relatedness and inbreeding level to avoid overestimations (NAMKOONG, 1966; SEBBENN, 2006; SQUILLACE, 1974). The 25 mother trees, from which the studied progenies were originated, were not inbred $\left(F_{m}<0\right.$, Table 1). Although the estimated outcrossing rate $\left(t_{m}\right)$ indicated that seeds of the progeny test were predominantly originated from outcrossing (0.782), there is a high variation among progenies (from 0.347 to 1.0 ), and many seeds were inbred by selfing in accordance with the progeny considered (Figure 1). We also detected certain levels of mating among relatives $\left(t_{m}-t_{s}=7.7 \%\right)$, which means that some outcrossed seeds are inbred. Both selfing and mating among relatives have contributed to the total inbreeding $\left(F_{o}=\right.$ $0.144)$. Furthermore, full-sibs were detected for some outcrossed seeds $\left(r_{p}=0.102\right)$ by the paternity correlation $\left(r_{p}\right)$. Thus, the progeny test showed mixtures of self-sibs, half-sibs, full-sibs, and selfhalf-sibs within progenies, besides unrelated individuals (among progenies), resulting in a mean relatedness $(\rho=0.421)$ within progenies higher than the expected for half-sibs $(\rho=0.25)$.

Selfing, mating among relatives, and correlated matings in $E$. grandis are similar to other studies on other species of the genus Eucalyptus. In E. grandis, outcrossing rates were estimated to range from 0.34 to 1.0 (BURGESS et al., 1996; CHAIX et al., 2003; JONES et al., 2008; MORAN; BELL, 1983 ) and for the hybrid E. grandis $\mathrm{x}$ urophylla from 0.86 to 0.93 (GAIOTTO et al., 1997; SILVA et al., 2015). In E. rameliana, the outcrossing rate was estimated at 0.89 and parental correlation at 0.09 (SAMPSON, 1998). Yet in E. camaldulensis, the outcrossing rate was estimated to be between 0.878 to 0.874 , and the parental correlation from 0.079 to 0.355 (BUTCHER; WILLIANS, 2002). Finally, in E. globulus, the outcrossing rate was estimated at 0.561 and parental correlation at 0.669 (PATTERSON et al., 2004).

\section{Genetic control of rust resistance}

Our results showed that rust resistance is under high genetic control. Among progenies, the heritability was close to the unit $\left(h_{f}^{2}=0.956\right)$; thereby one or a small number of loci control the trait, making genetic selection feasible. Other studies carried in Brazil with nine E. grandis progenies found similar results of $h_{f}^{2}$ for rust resistance (mean 0.91). Teixeira et al. (2009) proposed that a majoreffect locus could explain the resistance to $P$. psidii, since there are at least three different alleles with interactions among them, which would result in susceptibility or resistance phenotype. Equally, we observed a high genetic control at the individual level and within progenies. Nevertheless, assuming that within progeny plants are half-sibs and had heritability coefficients at the individual level $\left(h_{i}^{2}=1.067\right)$ and within progeny $\left(h_{w}^{2}=1.121\right)$ higher than the unity, which is the maximum value expected for these parameters; thus, we may assume the model was inadequate and may overestimate the parameters. We can clearly say that the cause was due to a wide range of relatedness levels within a progeny, which was originated from selfing and correlated matings detected by the mating system analysis through microsatellite loci. When we adjusted the additive genetic variance estimate for mating system parameters, these coefficients decreased $\left(h_{i}^{2}=0.634 ; h_{\psi}^{2}=0.515\right)$ until reaching acceptable values. The overestimation was very high, $68.5 \%$ for $h_{i}^{2}[100(1.067-0.634) / 0.634]$ and 
$117.7 \%$ for $h_{w}^{2}$ [100(1.121-0.515)/0.515]. Therefore, molecular markers are very useful tools to estimate heritability as well as the expected genetic gains from selection through open-pollinated progeny testing since these gains depend on heritability coefficients (NAMKOONG, 1979). On the other hand, even if $h_{i}^{2}$ and $h_{w}^{2}$ decreased after adjusting additive variance with mating system parameters, the adjusted values would continue to support a high genetic control of the resistance trait and a potential population improvement by mass selection. On the other hand, Miranda et al. (2013) detected a low genetic control by means of individual heritability ( $h_{i}^{2}$ ranging from 0.06 to 0.46 , with a mean of 0.24 ) and within progeny ( $h_{\psi}^{2}$ ranging from 0.04 to 0.34 , with a mean of 0.16 ), studying nine E. grandis populations through progeny testing in Brazil. In another study, Pinto et al. (2014) found moderate (heritability at the individual level) and high (among progenies heritability) heritability for rust resistance in E. dunni under controlled and field conditions. The differences between the above-cited studies and ours are because the heritability is a parameter that interacts with the environment. Additionally, Miranda et al. (2013) corrected the additive genetic variance using the relatedness coefficient, which was not calculated for each individual population but on the basis of mean outcrossing rate, selfing correlation $\left(r_{s}\right)$ and parental correlation $\left(r_{p}\right)$ from five different eucalyptus species (E. camaldulensis, E. globulus, E. morrisbyi, E. rameliana and E. marginata).

\section{CONCLUSION}

The characterization of mating systems using molecular markers showed that open-pollinated progeny test is not really a half-sib progeny test, since there is a wide range of relatedness levels within progenies from selfing and correlated matings, as well as inbred individuals. These facts resulted in overestimations of the genetic control of rust resistance among progenies and within progeny. However, after making the proposed correction, the estimates of the magnitude of the genetic influence on rust resistance showed the feasibility of improving the population of Eucalyptus grandis by mass selection among and within progenies.

\section{ACKNOWLEDGEMENTS}

We thank the Cia Suzano de Papel e Celulose for help with field work and the Fundação de Amparo à Pesquisa do Estado de São Paulo (FAPESP 02 /06713-4) (Foundation for Research Support of the State of São Paulo) for funding this research. Alexandre Magno Sebbenn thanks the Conselho Nacional de Desenvolvimento Científico e Tecnológico - CNPq (Brazilian Council for Scientific and Technological Development) for financial support.

\section{REFERENCES}

BRONDANI, R. P. V.; BRONDANI, C; TARCHINI, R.; GRATTAPAGLIA, D. Development, characterization and mapping of microsatellite markers in Eucaliptus grandis and E. urophylla. Theoretical and Applied Genetics, Berlin, v. 97, n. 5-6, p.816-827, 1998.

BURGESS, I. P.; WILLIAMS. E. R.; BELL, J. C.; HARWOOD, C. E.; OWEN, J. V. The effect of outcrossing rate on the growth of selected families of Eucalyptus grandis. Silvae Genetica, Frankfurt, v. 45, p. 97-100, 1996.

BUTCHER, P. A.; WILLIAMS, E. R. Variation in outcrossing rates and grown in Eucalyptus camaldulensis from the Petford Region, Queensland; Evidence of outbreeding depression. Silvae Genetica, Frankfurt, v. 51, p.65$72,2002$.

BUTCHER, P. A., GLEUBITZ, J. C.; MORAN, G. F. Applications for microsatellite markers in the domestication and conservation of forest trees. Forest Genetic Resources, Rome, v. 27, p. 34-42, 1999.

CHAIX, G.; GERBER, S.; RAZAFIMAHARO, V.; VIGNERON, P.; VERHAEGEN, D; HAMON, S. Gene flow estimation with microsatellites in a malagasy seed orchard of Eucalyptus Grandis. Theoretical and Applied Genetics, Berlin, v. 107, n. 4, p.705-712, 2003.

Sci. For., Piracicaba, v. 45, n. 114, p. 405-413, jun. 2017 DOI: dx.doi.org/10.18671/scifor.v45n114.16 
Bertoncini et al. - Rust resistance and mating system in Eucalyptus grandis Hill ex Maiden progenies

DOYLE, J. J.; DOYLE, J. L. Isolation of plant DNA from fresh tissue. Focus, Rockville, v. 12, p.13-15, 1990.

FERREIRA, F. A. Patologia Florestal: principais doenças no Brasil. Viçosa: SIF, 1989, 570 p.

FUCHS, M. C. P.; TAMBARUSSI, E. V.; LOURENCAO, J. C.; NOGUEIRA, L. M.; BORTOLOTO, T. M.; GONZALEZ, E. R.; ODA, S.; MARINO, C. L. Molecular marker associated with a deleterious recessive anomaly in Eucalyptus grandis seedlings. Annals of Forest Science, Nancy, v. 72, p. 1043 - 1052, 2015.

GAIOTTO, F. A.; BRAMUCCI, M.; GRATTAPAGLIA, D. Estimation of outcrossing rate in a breeding population of Eucalyptus urophylla with dominant RAPD and AFLP markers. Theoretical and Applied Genetics, Berlin, v. 95, n. 5-6, p.842-849, 1997.

GOUDET, J. Fstat. (Version 2.9.3.2.): a computer program to calculate F-statistics. Journal of Heredity, Cary, v. 86 , n. 6 , p. $485-486,1995$.

JOFFILY, J. Ferrugem do eucalipto. Bragantia, Campinas, v. 4, n. 8, p.475-487, 1944.

JONES, M. E.; SHEPHERD, M.; HENRY, R. H.; DELVES, A. Pollen flow in Eucalyptus grandis determined by paternity analysis using microsatellite markers. Tree Genetics \& Genomes, Berlin v. 4, n. 1, p.37-47, 2008.

KUHLMAN, E.G.; AMERSON, H. V.; JORDAN, A. P.; PEPPER, W. D. Inoculum density and expression of major gene resistance to fusiform rust disease in loblolly pine. Plant Disease, v. 81, n. 6, p.597-600, 1997.

MIRANDA, A. C.; MORAES, L. L. T.; TAMBARUSSI, E. V.; FURTADO, E. L.; MORI, E. S.; SILVA, P. E. M.; SEBBENN, A. M. Heritability for resistance to Puccinia psidii winter rust in Eucalyptus grandis Hill ex Maiden in Southwestern Brazil. Tree Genetics and Genomes, Berlin, v. 9, p.321-329, 2013.

MORAN, G. F; BELL, J. C. Eucalyptus. In: TANKSLEY, S. D.; ORTON, T. J. (Eds). Isozymes in Plant Genetics and Breeding, Part B. Amsterdam: Elsevier, 1983. p. 423-441.

NAMKOONG, G. Inbreed effects on estimation of genetic additive variance. Forest Science, Bethesda, v. 12, n. 1, p.8-13, 1966 .

NAMKOONG, G. Introduction to quantitative genetics in forestry. Washington, D.C.: Castle House Publications / Forest Service, 1979, (Technical Bulletin, 1588).

NEI, M. Estimation of average heterozygosity and genetic distance from a small number of individual. Genetics, Austin, v. 89, n. 3, p.583-590, 1978.

PATTERSON, B.; VAILLANCOURT, R. E.; PILBEAM, D. J.; POTTS, B. M. Factors affecting variation in outcrossing rate in Eucalyptus globulus. Australian Journal of Botany, Queensland, v. 52, p.773-780, 2004.

PINTO, C. S.; COSTA, R. M. L.; MORAES, C. B.; PIERI, C.; TAMBARUSSI, E. V.; FURTADO, E. L.; MORI, E. S. Genetic variability in progenies of Eucalyptus dunnii Maiden for resistance to Puccinia psidii. Crop Breeding and Applied Biotechnology, Viçosa, v. 14, n. 3, p.187-193, 2014.

RITLAND, K. Correlated matings in the partial selfer Mimulus guttatus. Evolution, Lancaster, v. 43, n. 4, p.848859, 1989.

RITLAND, K. Extensions of models for the estimation of mating systems using independent loci. Heredity, London, v. 88, n. 4, p.86-94, 2002.

RITLAND K.; JAIN. S. A model for the estimation of outcrossing rate and gene frequencies using $n$ independent loci. Heredity, London, v. 47, n. 1, p.35-52, 1981. 
RUIZ, R. A. R.; ALFENAS, A. C. Absorção e translocação de fungicidas sistêmicos em Eucalyptus grandis para o controle da ferrugem do eucalipto, causada por Puccinia psidii. Fitopatologia Brasileira, Brasília, v. 14, p.47-49, 1989.

SAMPSON, J. F. Multiple paternity in Eucalyptus rameliana (Myrtaceae). Heredity, London, v. 81, n. 3, p.349$355,1998$.

SAS INSTITUTE INC. SAS procedures guide. Version 8 (TSMO). Cary: SAS, 1999

SEBBENN, A. M. Sistema de reprodução em espécies arbóreas tropicais e suas implicações para a seleção de árvores matrizes para reflorestamentos ambientais. IN: HIGA, A. R.; SILVA, L. D.(EDS) Pomares de sementes de espécies nativas. Curitiba: FUDEP, 2006. p.193-198.

SILVA, P. H. M.; SEBBENN, A. M.; GRATTAPAGLIA, D. Pollen-mediated gene flow across fragmented clonal stands of hybrid eucalypts in an exotic environment. Forest Ecology and Management, Amsterdam, v. 356, p. 293-298, 2015.

SQUILLACE, A. E. Average genetic correlations among offspring from open-pollinated forest trees. Silvae Genetica, Frankfurt, v. 23, p.149-156, 1974.

TAKAHASHI, S. S.; FURTADO, E. L.; VALLE, C. F.; BONINE, C. A. V. Ocorrência e evolução da ferrugem do eucalipto em duas regiões do Estado de São Paulo. Fitopatologia Brasileira, Brasília, v. 22, p.254, 1997.

TEIXEIRA, J. E. C.; GUEDES, F. T. P.; DIAS, D. C.; BONINE, C. A. V.; CAMARGO, L. E. A. Análise da herança da resistência a Puccinia psidii em progênies de híbridos interespecíficos de eucalipto avaliadas sob condições naturais de infecção. Tropical Plant Pathology, Brasília, v. 34, n. 4, p.203-210, 2009.

VAILLANCOURTT, R. E.; SKABO, S.; GORE, P. L. Fingerprinting for quality control in breeding and deployment. Australian Forestry, Melbourne, v. 61, n. 3, p.207-210, 1998.

VASCONCELLOS, M. E. C.; VALOIS, A. C. C. Estimação de parâmetros genéticos em seringueira sem o emprego de testes de progênies. Pesquisa Agropecuária brasileira, Brasília, v. 21, n. 7, p.731-738, 1986.

ZAMPROGNO, K.C.; FURTADO, E. L.; MARINO, C. L.; BONINE, C. A; DIAS, D. C. Utilização de análise de segregantes agrupados na identificação de marcadores ligados a gene que controlam a resistencia à ferrugem (Puccinia psidii Winter) em Eucalyptus sp. Summa Phytopathol, Botucatu, v. 34, n. 3, p.253-255, 2008.

Recebido em 11/09/2016

Aceito para publicação em 28/03/2017

Sci. For., Piracicaba, v. 45, n. 114, p. 405-413, jun. 2017

DOI: dx.doi.org/10.18671/scifor.v45n114.16 
